\title{
Cost Reduction and Business Strategy Matters to Human Resource Outsourcing? A Validation by HR Experts from Government Link Companies (GLC's).
}

\author{
Mohd Fitri Mansor ${ }^{1, *}$, Noor Hidayah Abu ${ }^{2}$, Aida Nazima Abashah ${ }^{1,}$ Muhammad Asyraf Mohd Kassim ${ }^{1}$ \\ ${ }^{1}$ School of Business Innovation \& Technopreneurship, Universiti Malaysia Perlis, Jalan Kangar- Alor Setar, 01000 Kangar Perlis, \\ Malaysia. \\ ${ }^{2}$ School of Technology Management \& Logistic, College of Business, Universiti Utara Malaysia, 06010 Sintok, Kedah Malaysia.
}

\begin{abstract}
The phenomenon of outsourcing has spawned a rich body scholarly reseach in sveral decades. However, the answer to one of the pertinent question has remained elusive: Does cost reduction and business strategy really matters to the human resource outsourcing impacts. Looking at this question it is important for the organization to embark on the practice of human resource outsourcing to save operating cost and remain competitive. Therefore, the objective of this study is to investigate the effects of cost reduction and business starategy towards human resource outsourcing impacts. Both quantitative and qualitative methods were employed and the top management in Malaysian Government Link Companies (GLC') is the unit of analysis. The findings revelaved that, both variables are significant statistically and non statically i.e from the experts opinion. Finally, the study also provides useful directions for future research, HR Practitioners and policy maker particularly in managing and organizing human reseouce matters.
\end{abstract}

\section{Introduction}

Outsourcing is one of the most powerful trends in Human Resource Management (HRM). The growth in this, Human Resource Outsourcing (HRO), has promoted research into the optimal strategic conditions for externalization of HRM activities [20, 21, 35]. It refers to a contractual relationship for the provision of business service by an external provider or in simple words a company pays another company to do some work for it [4]. Again, Nordigarden et al (2014) [29] define outsourcing as the transference of internal governance activity to external control. It occurs when the organization contracts with another organization to provide service or products whether core or non-core activities. Works are traditionally done internally is shifted to an external provider and the employees of the said organization are sometime be transferred to the service provider.

The survey conducted by Gurchiek, (2005) [12] shown that nearly all organizations have outsourced parts of their HR functions. Intriguing facts some see outsourcing as a way of maintaining or increasing company competitiveness. However, many other views outsourcing in more negative light, focusing on job lost [38]. Failure to manage human resource outsourcing subject to risk in the organization such as reduces the organization capability for cross functional synergies and creativity. This risks and limitations, it is estimated between $1 \%$ to $20 \%$ of outsourced HR functions have been brought back in house $[12,31]$. Organizations that outsource due to trends or "everybody is doing it" possibly faced unexpected costs and complications. Based on previous studies by Lutchen, (2004) [23] about one-half of the outsourcing arrangements entered into end up being terminated for various reasons. Some new vendors encounter financial difficulties or acquired by other firms with different procedures and priorities. For example Indian operations in business processing such as call centers and office handling payroll, accounting and human resource functions often loss $15-20 \%$ of their workforces each year but the software programming skills are plenty, managerial experience is in very short supply (McKinsey Global Institute, 2003).

\subsection{Problem Statement}

HRO has grown popularly since early 1990 s, particularly in the USA and Europe. It is up to $90 \%$ of companies outsource some HRM activities (William, 2000; Banham, 2003; Cook, 1999). Based on previous study by Galanaki \& Papalexandris (2005), the positive implication of the company implementing the HR outsourcing is more efficient, economy of scale benefit, provide knowledge and competencies that is not available in house and able to reduce cost even more as compared to hiring staff to handle these HR activities. Again, it gains specialized HR expertise, achieving flexibility, reducing risks and enhancing access to advanced technology (Belcourt 2006; Lever, 1997; Scott et al., 2005). In addition, the benefits of HRO is also supported by Davidson (2005) where every organization entered in these activities reported that they significantly reduced HR costs through greater economies of scale, lower technology-investment costs, efficient HR processes and headcount reductions.

However, there are some issue and debate on HR outsourcing where it is seen as a threat that synonymous with downsizing or reductions in manpower that lead to generate little value to the core competence of the organization [8]. It is a danger in outsourcing some HR tasks while keeping others in-house. Major organizational

\footnotetext{
Corresponding author: fitrimansor@unimap.edu.my
} 
change become more difficult to achieve if part or whole of HR functions are outsourced, create rigidity, low morale and greater frustration among the employees that could leads to higher staff turnover [34]. Furthermore, it is still lack of study in the field of human resource outsourcing in the local context. The trend of outsourcing practice is widely practiced in manufacturing operations rather than government sector particularly in Government Link Companies [37] and indeed in some areas of business, outsourcing has been going on for quite some time. Despite an increase in HR outsourcing activities by organizations, research on this subject is not extensive [19] and is still at the seminal stage. Even though, the growth in HR outsourcing over the last decades has been remarkable, its effects are still vague and inexplicable [16].

Based on the above scenarios it shows that the gaps still exists between what is expected and the actual scenario particularly in human resource outsourcing practicing. In spite of the emerging trend in human resource outsourcing, few empirical investigations have been conducted into human resource outsourcing, particularly in Malaysia [14]. In fact, many studies emphasize outsourcing of other activities such as information technology [18], engineering [32], and manufacturing [9].

To some companies, it is still rarely applied the outsourcing to human resource function and more than that, it is a debatable issue whether this human resource outsourcing yield a good result or detrimental to the whole institution. In fact, results from the past studies are inconsistent [8]. Therefore, this study is pertinent for further investigate the impacts of cost reduction and business strategy towards HRO in Malaysia Government Link Companies (GLC's). The said findings then will be validated by HR Experts. Finally, the discussion and conclusion will be addressed.

\section{Literature Reviews}

\subsection{Cost Reduction}

Several studies are focusing on cost saving following outsourcing several activities to external experts. As for $[16,1]$, found evidence specifically linking outsourcing activity to cost saving in a way that firms with outsourcing implementation have an obvious significant advantage in term of cost efficiency compared to their counterpart with no single outsourcing approach at all.

In a study carried out among 51 publicly traded firm in US from 1990 to 2002 with applied outsourcing in their operations, authors have carried out the finding on which outsourcing can improve a firm's cost-efficiency [5]. Nevertheless the existing literature show that outsourcing improved their productivity and profitability. Previous researches has shown outsource activities to third party are proven to generate more productivity in businesses [24].

The objectives of outsourcing are to cut cost, enhancing productivity and time saving. According to Gilley (2000), [11] authors highlighted the need to outsourcing that can provide cost reduction to firm. This happen when the cost of upgrading maintenance in house is higher compare to outsourcing activities of hiring the third party expertise. For example, Malhotra (1995), [25] found that factors affected by outsourcing decisions are sharing risk on technology investment, operating cost reduction, access to specialized expertise, fixed cost due to the contract, and perception of efficiency. In addition, Bardhan et al (2006), [3] examined that the reason of why firm apply outsourcing is because it can increased capacity, higher quality of product and service and reduced cost.

In other setting, a study in UK workplace provides a detail acknowledgment by informant regarding the driving factors of HR outsourcing. Other than cost control and risk management gained, it is a relief for the HR specialist following the pressures they faced that drove them to consider outsourcing. Other outsourcing motivations besides reasons of cost and quality is a political and historical reason based on experience elsewhere in the business specifically influence of parent companies [40].

Dickmann and Tyson (2005), [7] conclude that the cost reduction was achieved through lesser investment made in IT software and future maintenance specifically made available for payroll function in HR. This research outlined of such advantage to a mediumsized organizations in payroll administration. Similarly, every company with adoption of outsourcing HR functions provide a significant reduction in HR costs through greater economies of scale efficient process, lower technology-investment costs and headcount reduction [7]. Based on the above reviews, the cost reduction can be hypothesized as following below:

H1: The cost reduction benefits has gained by adapting human resource outsourcing.

\subsection{Business Startegy}

Business strategy is a set of strategic statement that summarize on how an individual company will achieve its goals through meeting customer expectation and competitive advantage [17]. Business strategy can be defined in either several paragraphs or be written as a set of strategic statements. It is important to any organization since it is the determinant to the direction of business and what it will look like in the future. The elements in business strategy are core business activity, sharing and reducing risk, establishing strategic partnership, gaining recognition, raising innovation and streamline internal function. By defining business strategy clearly, organization can develop business or growth plan to achieve business and personal goals. Once it is defined, business strategy sets priorities for the company and management team and helps attract and retain the talented workers the organization need. Although each department in company may focus on different priorities to accomplish specific tasks, these priorities should have no conflict with the overall strategic direction of the company. 
The strategy of business somehow indirectly related to human resource function. A study by Galanaki and Papalexandris (2005), [10] showed less developed country like Greece specifically in view of small size companies may benefit from service of HRO with the aim to improve human resource practices in order to increase competitiveness through people. The appropriate use of customization and sophistication of services from vendors could act as key players in the development of human resource function that eventually covered up for the lack of in-house resources.

HRO activity is associated with increasing partnership quality in a way that trust existed as an important component in establishing partnership. The trust leads to positive relationship building and establish the partnership quality which in turn yield a business strategy in partnership [13]. The effect can be seen in firms profit which depending on the ability of outsourcing partner to support the operation.

In addition, business strategy will help developing human resource management. It is a summary of how a company will achieve its goals, meet the expectations of its customers, and sustain a competitive advantage in the marketplace. Business strategy highlight why the company is in business, what is their competitive advantage, which customer should be focused, with what product or service should they continue to offer and why certain strategic direction is decided.

There is a relationship between business strategy and human resource outsourcing which is based on 4 distinctive business strategy integrated from [27, 28 33], which include quality-based, proactive, breadth and reactive strategy. For instance, organizations with a quality-based strategy will find it beneficial to outsource HR transactional function that include payroll and benefits while keeping recruitment function in the company. This is to enable company to enact policies that necessary to attract good candidates.

As for organization with reactive business strategy will prefer not to outsource all HR functions which are both transactional and traditional since their aim is to reduce overall cost. Therefore, Halim and Cheha (2009), [13] have found a positive significant association between proactive business strategy and HR outsourcing of both functions. The HR outsourcing helps business to be more focused on creating innovative and differentiate products. Therefore, the business strategy can be hypothesized as:

H2: The business strategy will be achieved by adapting human resource outsourcing

\section{Findings and Discussion}

\subsection{Quantitaive Findings}

This study employed both quantitative and qualitative approaches by surveying employees working in Malaysia Government Link Companies (GLC). A total of 400 sets of questionnaire were distributed and 301 sets are usable. The data analyses were employed for quantitative are descriptive analysis, correlation analysis, reliability analysis and regression analysis.

\subsubsection{Reliability Analysis}

The reliability test was used for each variable to provide constant results and it is confirmed that there are no errors in the information provided. Table 1 showed the results of the reliability analysis test using the Cronbach Alpha for all variables. The Cronbach Alpha for value for all variables are $.967, .971$ and .969 for cost reduction, business strategy and HRO respectively. The reliability test shows that the variables are reliable and excellent. All of values are above .900 for the analysis conducted represent excellent. Hinton et al., (2004) have suggested four cut-off points for reliability, which includes excellent reliability for 0.90 and above, high reliability between $0.70-0.90$, moderate reliability the range between $0.50-0.70$ and low reliability between 0.50 and below. The higher Cronbach's Alpha values for all constructs represents they are internally consistent.

Table 1. Reliability Analysis

\begin{tabular}{lcccl}
\hline Constructs & $\begin{array}{c}\text { Sample } \\
\text { Size (n) }\end{array}$ & $\begin{array}{c}\text { No. of } \\
\text { items }\end{array}$ & $\begin{array}{c}\text { Cronbach's } \\
\text { Alpha (o) }\end{array}$ & Indication \\
\hline Cost Red. & 301 & 10 & .967 & Excellent \\
Buss. Strg & 301 & 10 & .971 & Excellent \\
HRO & 301 & 8 & .969 & Excellent \\
\hline
\end{tabular}

\subsubsection{Regression Analysis}

Regression analysis is a family of technique to explore the relationship between one continuous dependent variable and multiple independent variables [30]. Therefore, this analysis allows more sophisticated exploration of the interrelationship among variables. Refering to the Table 2 below, it contains several results such as beta, significant, R square and few more others. Each serves a different interpretation for data analysis. The beta with the largest value means that it makes the strongest unique contribution to explain the dependent variable. For the significant, the value with less than 0.05 is the variable that makes a significant unique contribution to the prediction of the dependent variable while value that is greater than 0.05 can be conclude with no significant unique contribution to the prediction of dependent variable. As for adjusted $\mathrm{R}$ square, it corrects the $\mathrm{R}$ square to provide a better estimate of the true population value in case a small sample is involved in the study.

The regression analysis result is computed in the Table 2 which was used to examine the independent variable and dependent variables. The results of regression analysis, it showed that hypothesis $1(\mathrm{H} 1)$ has a positive and significant value .000 and with standardized coefficients (beta) 2.12 and t value is 3.702 . The significant value of .00 is smaller than 0.05 which showed that the hypothesis is supported. Hence, the alternative hypothesis $(H \alpha)$ shows significant impact on cost reduction towards HRO and is accepted. 
Hypothesis $2(\mathrm{H} 2)$ has a positive and significant value .000 and with standardized coefficients (beta) .534 and $t$ value is 10.234 , the significant value of .000 is smaller than 0.05 which showed that the hypothesis is supported. Hence, the alternative hypothesis $(H \alpha)$ shows significant impact of business stategy towards HR outsourcing and is accepted. In addition, the R-square value of 0.693 indicates that $69.3 \%$ of the variance in the study can be explained by cost reduction and business strategy.

Table 2. Regression Analysis

\begin{tabular}{cccccc}
\hline \multicolumn{2}{c}{$\begin{array}{c}\text { Unstandardized } \\
\text { coefficients }\end{array}$} & \multicolumn{4}{c}{$\begin{array}{c}\text { Standardized } \\
\text { coefficients }\end{array}$} \\
\hline Model & $\mathrm{B}$ & $\begin{array}{c}\text { Std. } \\
\text { error }\end{array}$ & Beta & $\mathrm{t}$ & $\mathrm{sig}$ \\
\hline $\begin{array}{c}\text { Cost } \\
\text { Reduction } \\
\text { Business } \\
\text { Strategy }\end{array}$ & .202 & 055 & .212 & 3.702 & .000 \\
\hline \multicolumn{5}{c}{$\begin{array}{c}\text { R Square }=.693 \\
\text { Adjusted R square }=.756 \\
\text { Durbin-Watson }=2.058\end{array}$} \\
\end{tabular}

\subsubsection{Correlation Analysis}

Correlation analysis is used to describe the strength and direction of the linear relationship between variables. The strength of relationship is shown in $r$ value while negative or positive sign of $r$ value is used to determine the direction of the relationship. From the Table 3 below, the relationship between two independent variables (cost reduction and business strategy) and dependent variable (human resources outsourcing) are shown. First correlation is between cost reduction and human resources outsourcing the r-value are 0.770 or 77 percent at 99 percent confident interval. These values represent a very strong relationship. Meanwhile the correlation continues to correlate between business strategy and human resource outsourcing. The r-value is 0.844 or $84.4 \%$ confident interval and it is representing very strong relationship.

Table 3. Correlation Analysis

\begin{tabular}{lccc}
\hline & $\begin{array}{c}\text { Cost } \\
\text { Reduction }\end{array}$ & $\begin{array}{c}\text { Business } \\
\text { Strategy }\end{array}$ & HRO \\
\hline Cost Red. & 1 & & \\
Buss Strg. & $.756^{* *}$ & 1 & \\
HRO & $.770^{* *}$ & $.844^{* *}$ & 1 \\
\hline$* *$ Correlation is significant at the .01 level (2-tailed) & \\
$*$ Correlation is significant at 0.5 levels (2-tailed) &
\end{tabular}

\subsection{Qualitative Findings}

The study also employed qualitative method apart from questionnaire distribution. This method conducted done after quantitative data were analyzed and it is used for validation and comparison. Several HR practitioners representing each of GLCs were interviewed for this purpose and the results are summarized in the tables below.

Table 4. Content Analysis GLC A

\begin{tabular}{|c|c|c|}
\hline & \multicolumn{2}{|c|}{ GLC A } \\
\hline Question & \multicolumn{2}{|c|}{ Feedback } \\
\hline Respondent & \multicolumn{2}{|c|}{$\begin{array}{ll}\text { Position } & \text { : Human Resource Manager } \\
\text { Gender } & : \text { Male } \\
\text { Experience } & : \text { : } 0 \text { years } \\
\text { Education } & : \text { Degree } \\
\text { Job Scope } & \text { : System Administrator (HRIS) } \\
\text { Sector } & \text { : Utility } \\
\end{array}$} \\
\hline $\begin{array}{c}\text { HR } \\
\text { Outsourcing } \\
\text { Activities }\end{array}$ & $\begin{array}{ll}\text { - } & \text { Ground work / } \\
\text { technical } \\
\text { - }\end{array}$ & $\begin{array}{l}\text { - Training and } \\
\text { development }\end{array}$ \\
\hline $\begin{array}{l}\text { Cost } \\
\text { Reduction }\end{array}$ & \multicolumn{2}{|c|}{$\begin{array}{l}\text { - The HR expert agrees the statement that } \\
\text { outsourcing some HR functions help } \\
\text { reduced firm's operational cost. This can } \\
\text { be seen from the point of monitoring } \\
\text { employees in implementing their work at } \\
\text { the workplace. The job being outsourced } \\
\text { is high risks in which the employees are } \\
\text { exposed to an accident or injury. By } \\
\text { delegating the tasks of non-core activities } \\
\text { to vendors, it eventually leads to time } \\
\text { saving in HR management and } \\
\text { operational cost. } \\
\text { HR manager recognized some cost } \\
\text { reduction in seeking new employees. The } \\
\text { company is recruiting new employees for } \\
\text { the purpose of its core activities while } \\
\text { workers for non-core activities are } \\
\text { employed by the vendor in outsourcing. } \\
\text { In-house workers are given works that has } \\
\text { nothing to do with functions being } \\
\text { outsourced. It does not lead to time saving } \\
\text { since jobs for in-house employees are not } \\
\text { reduced. }\end{array}$} \\
\hline $\begin{array}{l}\text { Business } \\
\text { Strategy }\end{array}$ & \multicolumn{2}{|c|}{$\begin{array}{l}\text { - Although vendors are in charge of the } \\
\text { labors, yet the risks are on the company to } \\
\text { be accounted for any possible accidents } \\
\text { occur. This is stated in Energy } \\
\text { Commission Act as a new regulator for } \\
\text { the energy industry in Malaysia which } \\
\text { stipulates that the organization should } \\
\text { accountable for any accident occurred. } \\
\text { Vendors play a crucial role in reaching } \\
\text { the GLC's main objective of serving } \\
\text { Malaysia users. It is important that the } \\
\text { vendors are available whenever they are } \\
\text { needed to support the organization. } \\
\text { Outsourcing assist in HR coordination in } \\
\text { a long term even though it is quite } \\
\text { difficult to be dealt particularly at the } \\
\text { early stage of outsourcing. } \\
\text { Since outsourcing is crucial for this GLC, } \\
\text { it does help making up for the lack of in- } \\
\text { house resources. }\end{array}$} \\
\hline
\end{tabular}


Table 5. Content Analysis GLC B

\begin{tabular}{|c|c|c|}
\hline & \multicolumn{2}{|c|}{ GLC B } \\
\hline Question & \multicolumn{2}{|c|}{ Feedback } \\
\hline Respondent & \multicolumn{2}{|c|}{$\begin{array}{ll}\text { Position } & \text { :General Manager (Human } \\
\text { Resource) } & \\
\text { Gender } & \text { :Male } \\
\text { Experience } & : 11 \text { Years and above } \\
\text { Education } & \text { :Degree } \\
\text { Job Scope } & \text { :Human Resource } \\
\text { Sector } & \text { :Finance and banking }\end{array}$} \\
\hline $\begin{array}{c}\text { HR } \\
\text { Outsourcing } \\
\text { Activities }\end{array}$ & 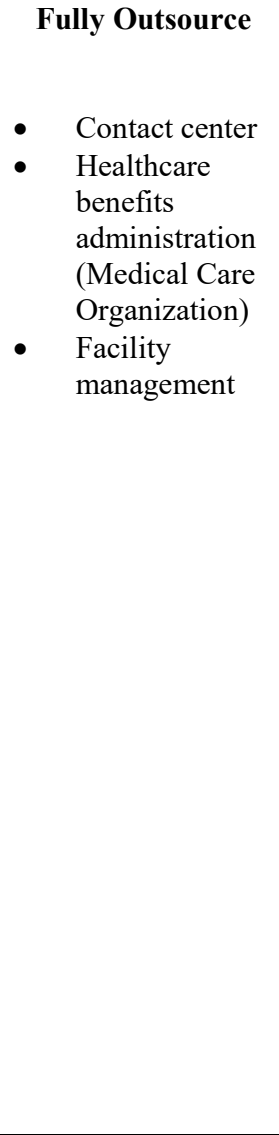 & $\begin{array}{l}\text { Partially Outsource } \\
\text { - } \\
\text { Recruitment and } \\
\text { selection } \\
\text { (supporting staff) } \\
\text { Talent } \\
\text { management } \\
\text { (Training and } \\
\text { development) } \\
\text { Executive } \\
\text { development and } \\
\text { Coaching } \\
\text { Compensation and } \\
\text { Benefit (C\&B) } \\
\text { Employees } \\
\text { assistance and } \\
\text { counseling } \\
\text { Employees' } \\
\text { communication } \\
\text { plans and } \\
\text { strategies. } \\
\text { Retirement } \\
\text { planning and } \\
\text { pension } \\
\text { administration } \\
\text { HR policy } \\
\text { development and } \\
\text { implementation } \\
\text { HR strategic } \\
\text { planning }\end{array}$ \\
\hline $\begin{array}{l}\text { Cost } \\
\text { Reduction }\end{array}$ & \multicolumn{2}{|c|}{$\begin{array}{l}\text { - At the initial implementation stage of } \\
\text { outsourcing there are considerable amount } \\
\text { of money involved. Nevertheless, the } \\
\text { advantages of cost reduction are apparent } \\
\text { to the GLC in a long term. For instance, } \\
\text { depending on the market condition which } \\
\text { alters the cost, the delegation of some } \\
\text { functions to Medical Care Organization } \\
\text { (MCO) is overly optimistic. This is } \\
\text { happening due to the extensive knowledge } \\
\text { as well as experiences of MCO in offering } \\
\text { the best recovery plan for employees } \\
\text { according to their injury. } \\
\text { It also benefits to the GLC in term of } \\
\text { reducing the cost of employee recruitment } \\
\text { since vendor directly involve in recruiting } \\
\text { its own employees. } \\
\text { Timing is crucial and this factor is taken } \\
\text { into account when considering the } \\
\text { outsourcing of HR function. Thus, the } \\
\text { time consumed for any function such as } \\
\text { healthcare and benefit are outsourced to } \\
\text { vendors. }\end{array}$} \\
\hline
\end{tabular}

\begin{tabular}{|l|l|}
\hline & $\begin{array}{l}\text { Sometimes works can be reduced by using } \\
\text { a third-party. In this company, a healthcare } \\
\text { division has a responsible party for } \\
\text { managing health-related problems that can } \\
\text { be reduced workload and time. }\end{array}$ \\
\hline Business & $\begin{array}{l}\text { Employees' healthcare, without doubt, is a } \\
\text { great relief to this GLC since this activity } \\
\text { is being outsourced to the Medical Care } \\
\text { Organization (MCO) no further } \\
\text { grievances and complaints received } \\
\text { compared than handled by in-house HR } \\
\text { experts. It has reduced the risk of } \\
\text { mishandling towards the cases. } \\
\text { There are many ways in which } \\
\text { outsourcing helps this GLC in managing } \\
\text { employees. Many improvement and } \\
\text { adjustment is made to cope with the } \\
\text { environment and the practice of HR } \\
\text { activities. } \\
\text { Outsourcing recognized by HR manager to } \\
\text { facilitate various activities starting from } \\
\text { recruitment to the benefit administration. } \\
\text { The outsourcing implementation has } \\
\text { covered up several deficiencies in training, } \\
\text { recruitment, paper work and employee } \\
\text { job-related assessment and helps the } \\
\text { organization in in-house resources. }\end{array}$ \\
\hline
\end{tabular}

\section{Conclusion}

In the nutshell, the current study is about the impacts of human resource outsourcing in Malaysian Government Link Companies (GLC's). Two variables carried out which are cost reduction and business startegy. A study employed both quantitative \& qualitative methods in order to answer the research objectives. In addition, the results gained from the quantitative then validated from several HR experts. The study revealed that, the cost reduction and business strategy are positively impact HRO in Malaysian Government Link Companies from the statically and non statically evidences. The findings of the current study may help the government in updating and reviewing manpower policy in the future, as a basis of human resource outsourcing decision as well as a foundation for future research in investigating any new variables in human resource outsourcing filed.

\section{References}

1. Banerjee, A. and Williams, A. S. International service outsourcing: Using offshore analytics to identify determinants of value-added outsourcing. Strategic Outsourcing: An International Journal, 2, $1(2013)$

2. Banham, R., HR Outsourcing Leads the Way. Outsourcing Essentials, 1, 30 (2003)

3. Bardhan, I., Whitaker, J. W., \& and Mithas, S. Information Technology, Production Process Outsourcing, and Manufacturing Plant Performance. Journal of Management Information Systems, 23, 2 (2006) 
4. Belcourt, M. Outsourcing; the benefits and the risk. Human Resource Management Review, 162 (2006)

5. Bin Jiang, G. V. Outsourcing effects on firms' operational performance: An empirical study. International Journal of Operations \& Production Management, 26 12,(2006)

6. Cook, M. Outsourcing Human Resources Functions. Startegies for Providing Enhanced HR Services at Lower Cost, AMACOM, New York, NY. (1999)

7. Davidson, G. Why HR outsourcing continues to expand. Human Resource Management International Digest, 133 (2005)

8. Delmotte, J. and Luc Sels. HR Outsourcing: Threat or opportunity. Personnel Review, 375 (2005)

9. Dekkers, R., Decision models for outsourcing and core competences in manufacturing. International Journal of Production Research, 387 (2000)

10. Galanaki, E. and Papalexandris, N. Outsourcing of human resource management services in Greece. International Journal of Manpower, 264 (2005)

11. Gilley, K. M. Making more by doing less: An analysis of outsourcing andits effects on firm performance. Journal of Management, 264 (2000)

12. Gurchiek, K. Record Growth: Outsourcing of HR Functions. HR Magazine, 506 (2005)

13. Halim, A. H. \& Che-Ha A. G. The influence of business strategy on the decision to outsource human resource activities. Journal of Human Resource Costing \& Accounting, 134 (2009)

14. Hasliza A.H., N. C. (2011). Embarking on HR Outsourcing- Do Organizational Size and Maturity Level Matter? Int. Journal of Economics and Management, 51 (2011

15. Hinton, P. R., Brownlow, C., McMurray, I \& Cozens, B. SPSS explained. Routledge Inc., East Sussex, England. (2004).

16. Jiang, B., Frazier, V. G. and Prater, L. E. Outsourcing effects on firms' operational performance. International Journal of Operations \& Production Management, 2612 (2006)

17. Kauffman, F. Defining your business strategy. retrieved form http://www.entrepreneurship.org/resourcecenter/defining-your-business-strategy.aspx (2015)

18. Lacity, M.C. and Willcocks, L.P. An empirical investigation of information technology sourcing practices: Lessons from experience. MIS Quarterly, 22 (1998)
19. Leiblein, M.J., Reuer, J.J. and Dalsace, F. Do 'make or buy' decisions matter? The influence of organizational governance on technological performance. Strategic Management Journal, 23 (2002)

20. Lawler, E.E., Ulrich, D., Fitz-enz, J. and Madden, J.C. Human Resource Business Process Outsourcing; Transformiong How HR Gets its Work Done. Jossey-Bass, San Francisco, CA. (2004)

21. Lepak, D.P. and Snell, S.A. Virtual HR: Strategic Human Resource Management in the $21^{\text {st }}$ century. Human Resource Management Review, 83 (1998)

22. Lever, S. An analysis of managerial motivations behind outsourcing practices in human resources. Human Resource Planning, 202 (1997)

23. Lutchen, M. Outsourcing IT headaches is no answer. Chief Executive, (2004)

24. M.Lindsay, J. R. (2001). The Management and Control of Quality, Fifth Edition.

25. Malhotra, Y. IS productivity and outsourcing policy: A conceptual framework and empirical analysis. Proceedings of Inaugural America's Conference on Information Systems (Managerial Papers). Pittsburgh, PA: Association for Information Systems.

26. McKinsey Global Institute. Offshoring: Is it a winwin game? San Francisco, Author. (2003)

27. Miles, R. E. and Snow, C. C. Organizational strategy, structure and process. McGrraw-Hill, New York, NY. (1978)

28. Miller, P. Strategic industrial relations and human resouce management: Distinction, definition and recognition. Journal of Management Studies, 244 (1987)

29. Nordigarden, D., Rehme, J., Brege, S., Chicksand, D. and Walker, H. Outsourcing decisions. The case of parallel production. International Journal of Operations \& Production Management, 348 (2014)

30. Pallant, J. SPSS Survival Manual: A step by step guide to data analysis using IBM SPSS. $5^{\text {th }}$ Edition. (2013)

31. Pollitt, D. Outsourcing HR: The contrasting experiences of Amex and DuPont, Human Resource Management, 12 6 (2004)

32. Quin, J. B. Outsourcing innovation - the new engine of growth, Sloan Management Review, 414 (2000) 
33. Schuler, R. S. and Jackson, S. E. Linking competitive strategy with human resource management practices. Academy of Management Executive, 3 (1987).

34. Sim, M. The intangible costs of human resource outsourcing, Human Resource Management International Digest, 18 (2010)

35. Stroh, L.K. and Treehuboff, D. Outsourcing HR Functions: when-and when not-to go outside, Journal of Leadership and Organizational Studies, 10 1, (2003)

36. Scott-Jackson, W., Newham, T. and Gurney, M. HR Outsourcing: The key decisions, Charted Institute of Personnel and Development, London. (2005)

37. Wahrenburg, M., Hackethal, A., Friedrich, L. and Gellrich, T. Strategic decisions regarding the vertical integration of human resource organizations: evidence for an integrated HR model for the financial services and non-financial services in Germany, Austria and Switzerland. International Journal of Human Resource Management, 1710 (2006)

38. Weidenbaum M. Outsourcing : Prons and Cons", Business Harizons, 481 (2005),

39. William M. Mercer and Cranfield School of Management. European Trends in HR Outsourcing, William M.Mercer and Cranfield School of Management, research report (2000)

40. Woodall, J., Jackson, S. W., Newham, T. and Gurney, M. (2009). Making the decision to outsource human resource. Personnel, Review, Vol. 38 Iss pp. 236252 